Article

\title{
Mono- and Dimeric Naphthalenones from the Marine-Derived Fungus Leptosphaerulina chartarum 3608
}

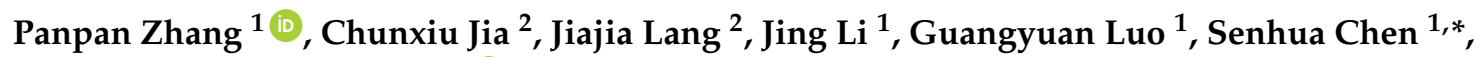 \\ Sujun Yan ${ }^{2, *}$ and Lan Liu ${ }^{1,3}$ (D) \\ 1 School of Marine Sciences, Sun Yat-sen University, Guangzhou 510006, China; \\ zhangpp23@mail2.sysu.edu.cn (P.Z.); Lijing356@mail.sysu.edu.cn (J.L.); luogy331@gmail.com (G.L.); \\ cesllan@mail.sysu.edu.cn (L.L.) \\ 2 School of Chemistry, Sun Yat-sen University, Guangzhou 510006, China; jiachx@mail2.sysu.edu.cn (C.J.); \\ langjj@mail2.sysu.edu.cn (J.L.) \\ 3 Key Laboratory of Functional Molecules from Oceanic Microorganisms (Sun Yat-sen University), \\ Department of Education of Guangdong Province, Guangzhou 510080, China \\ * Correspondence: chensenh@mail.sysu.edu.cn (S.C.); cesyansj@mail.sysu.edu.cn (S.Y.); \\ Tel.: +86-20-84725459 (S.C.)
}

Received: 11 April 2018; Accepted: 11 May 2018; Published: 21 May 2018

\begin{abstract}
Five new naphthalenones, two enantiomers (-)-1 and (+)-1 leptothalenone A, (-)-4,8-dihydroxy-7-(2-hydroxy-ethyl)-6-methoxy-3,4-dihydro-2H-naphthalen-1-one ((-)-2), (4S, $10 R, 4$ 'S)-leptotha-lenone B (5), (4R, 10S, 4'S)-leptothalenone B (6), and a new isocoumarine, 6-hydroxy-5,8-dimethoxy-3-methyl- $1 H$-isochromen-1-one (4), along with two known compounds (+)-4,8-dihydroxy-7-(2-hydroxy-ethyl)-6-methoxy-3,4-dihydro-2H-naphthalen-1-one ((+)-2) and (+)-10-norparvulenone (3) were isolated from the marine-derived fungus Leptosphaerulina chartarum 3608. The structures of new compounds were elucidated by HR-ESIMS, NMR, and ECD analysis. All compounds were evaluated for cytotoxicity and anti-inflammatory activity. Compound 6 showed moderate anti-inflammatory activity by inhibiting the production of nitric oxide (NO) in lipopolysaccharide-stimulated RAW264.7 cells, with an $\mathrm{IC}_{50}$ value of $44.5 \mu \mathrm{M}$.
\end{abstract}

Keywords: Leptosphaerulina chartarum; naphthalenones; isocoumarine; anti-inflammatory

\section{Introduction}

Marine-derived micro-organisms are known as a rich source of natural products with novel structure and interesting bioactivities [1]. A large number of the new compounds from marine-derived fungi are discovered every year. Among these, naphthalenone derivatives are side products of the 1,8-dihydroxynaphthalene polyketide pathway [2], which are common in the secondary metabolites from fungi with diverse bioactivities, such as antimicrobial [3], antiviral [4], cytotoxic [5], and antimalarial activities [3]. Besides, naphthalenone derivatives have structural diversity not only in the planar structure but also in the absolute configuration. Abdel-Latef et al. reported a pair epimer of $\left(3 R^{*}, 4 S^{*}\right)$-3,4-dihydroxy-7-methyl-3,4-dihydro-1(2H)-naphthalenone and $\left(3 S^{*}, 4 S^{*}\right)$-3,4-dihydroxy-7-methyl-3,4-dihydro-1(2H)-naphthalenone from the Algicolous marine fungus Acremonium sp. [6]. Wang et al. isolated a pair of naphthalenone enantiomers, corynenones $\mathrm{A}$ and B, from sponge-derived fungus Corynespora cassiicola [7].

During our ongoing research on secondary metabolites from marine-derived fungus, five new naphthalenones, two enantiomers (-)-1 and (+)-1 leptothalenone A, (-)-4,8-dihydroxy-7-(2-hydroxyethyl)-6-methoxy-3,4-dihydro-2H-naphthalen-1-one ((-)-2), (4S, 10R, 4'S)-leptothalenone B (5), 
$\left(4 R, 10 S, 4^{\prime} S\right)$-leptothalenone B (6), and a new isocoumarine (4), along with two known compounds (+)-4,8-dihydroxy-7-(2-hydroxy-ethyl)-6-methoxy-3,4-dihydro-2H-naphthalen-1-one ((+)-2) and $(+)$-10-norparvulenone (3) (Figure 1) were isolated from Leptosphaerulina chartarum 3608 from a crinoid collected in Xuwen, Zhanjiang City, Guangdong Province, China. In this paper, we described the structure determination of the new compounds as well as the bioactivity assay of these isolated compounds from the $\mathrm{CHCl}_{3}$ extract of L. chartarum 3608.<smiles>COc1cc2c(c(O)c1C(=O)O)C(=O)CC[C@H]2O</smiles>

$(-)-1$<smiles></smiles>

$(-)-2$<smiles>COc1cc2c(c(O)c1[C@H](C)O)C(=O)CC[C@@H]2O</smiles>

$(+)-1$<smiles>COc1cc2c(c(O)c1CCO)C(=O)CC[C@H]2O</smiles>

$(+)-2$<smiles>COc1cc2c(c(O)c1CO)C(=O)CC[C@H]2O</smiles>

3<smiles></smiles><smiles>COc1cc2c(c(O)c1CO[C@H]([Tl])c1c(O)cc3c(c1O)C(=O)CC[C@H]3O)C(=O)CC[C@@H]2O</smiles>

5<smiles>COc1cc2c(c(O)c1CO[C@H](C)c1c(OC)cc3c(c1O)C(=O)CC[C@@H]3O)C(=O)CC[C@H]2O</smiles>

6

Figure 1. Chemical structures of 1-6.

\section{Results and Discussion}

Compound $( \pm)-\mathbf{1}$ was obtained as a light brown powder and had a molecular formula $\mathrm{C}_{13} \mathrm{H}_{16} \mathrm{O}_{5}$ according to the positive HR-ESIMS ion at $m / z 275.0885[\mathrm{M}+\mathrm{Na}]^{+}$(calculated for $\mathrm{C}_{13} \mathrm{H}_{16} \mathrm{O}_{5} \mathrm{Na}$, 275.0890), indicating six degrees of unsaturation. The ${ }^{1} \mathrm{H}$ NMR data (Table 1) revealed the presence of one five-substituted aromatic proton $\left[\delta_{\mathrm{H}} 6.79(1 \mathrm{H}, \mathrm{s}, \mathrm{H}-5)\right]$, one methoxyl $\left[\delta_{\mathrm{H}} 3.92(3 \mathrm{H}, \mathrm{s}, \mathrm{H}-9)\right]$, one methyl $\left[\delta_{\mathrm{H}} 1.48(3 \mathrm{H}, \mathrm{d}, J=6.8, \mathrm{H}-11)\right]$, two methenes $\left[\delta_{\mathrm{H}} 2.62(1 \mathrm{H}, \mathrm{m}, \mathrm{H}-2), \delta_{\mathrm{H}} 2.79(1 \mathrm{H}, \mathrm{m}, \mathrm{H}-2)\right.$, $\left.\delta_{\mathrm{H}} 2.01(1 \mathrm{H}, \mathrm{m}, \mathrm{H}-3), \delta_{\mathrm{H}} 2.26(1 \mathrm{H}, \mathrm{m}, \mathrm{H}-2)\right]$, two oxygenated methines $\left[\delta_{\mathrm{H}} 4.77(1 \mathrm{H}, \mathrm{dd}, J=8.9,3.9\right.$, $\left.\mathrm{H}-4), \delta_{\mathrm{H}} 5.31(1 \mathrm{H}, \mathrm{s}, \mathrm{H}-11)\right]$. The ${ }^{13} \mathrm{C}$ NMR and DEPT spectra displayed a ketone carbonyl $\left(\delta_{\mathrm{C}} 204.6\right)$, six aromatic carbons $\left(\delta_{\mathrm{C}} 164.8,162.7,150.2,119.1,111.1,102.2\right)$, an oxygenated methyl $\left(\delta_{\mathrm{C}} 56.4\right)$, two oxygenated methine $\left(\delta_{C} 68.6\right.$ and 63.4$)$, and two methylenes $\left(\delta_{C} 36.1\right.$ and 32.7). Further analyses of the NMR data showed that compound 1 shared a good similarity with the known compound O-methylasparvenone [8], except for an extra hydroxyl group which was connected to C-10 based on the chemical shift values $\left(\delta_{\mathrm{H} / \mathrm{C}} 5.31\right.$ and $63.4, \mathrm{H}-10$ and $\left.\mathrm{C}-10\right)$ and the ${ }^{1} \mathrm{H}-{ }^{1} \mathrm{H}$ COSY correlation of $\mathrm{H}-10$ and $\mathrm{H}-11$, as well as the HMBC correlation of $\mathrm{H}-11$ with $\mathrm{C}-10$ and $\mathrm{C}-7$. Thus, the planar structure of 1 was successfully assigned as 9-hydroxyl-O-methylasparvenone (Figure 1).

Compound $\mathbf{1}$ was of racemic nature because it lacked any CD (circular dichroism) maximum and optical rotation. Subsequent chiral HPLC purification of $( \pm)-\mathbf{1}$ led to the separation of the two enantiomers, (-)-1 and (+)-1 (Figure $2 \mathrm{a})$, which showed opposite optical rotations $\left[(-)-\mathbf{1}\left([\alpha]_{D}^{20}=-24.8\right.\right.$, $c 0.47, \mathrm{MeOH})$ and $\left.(+)-\mathbf{1}\left([\alpha]_{D}^{20}=27.9, c 0.30, \mathrm{MeOH}\right)\right]$ and opposite Cotton effects in their CD spectra (Figure $2 b$ ). The experimental ECD spectra of (-)-1 exhibited negative Cotton effects (CEs) at 214, $310 \mathrm{~nm}$, and positive CEs at 238, $282 \mathrm{~nm}$, while (+)-1 exhibited positive CEs at $214,310 \mathrm{~nm}$, and negative CEs at $238,282 \mathrm{~nm}$. To determine the absolute configuration of (-)-1 and (+)-1, their theoretical ECD 
spectra of four possible configurations $[(4 R, 10 R)-\mathbf{1},(4 R, 10 S)-\mathbf{1},(4 S, 10 R)-\mathbf{1},(4 S, 10 S)-\mathbf{1}]$ were calculated by a quantum chemical method at the $[B 3 L Y P / 6-311+G(2 d, p)]$ level and are shown in Figure $2 b$. The predicted ECD curve of $(4 R, 10 R)-\mathbf{1}$ was in accordance with the experimental ECD curve of $(-)-\mathbf{1}$, and $(4 S, 10 S)-\mathbf{1}$ was also in agreement with the experimental ECD curve of $(+)-\mathbf{1}$ (Figure $2 \mathrm{~b})$. This result suggested that the absolute configuration of (-)-1 was $4 R, 10 R$ and (+)-1 was $4 S, 10 S$. Therefore, $( \pm)-\mathbf{1}$ was named as $( \pm)$-leptothalenone A.

Table 1. ${ }^{1} \mathrm{H}$ (400 MHz) NMR data of compounds 1, 2, and 4-6 (in $\mathrm{CD}_{3} \mathrm{OD}$, J in $\mathrm{Hz}$ ).

\begin{tabular}{|c|c|c|c|c|c|}
\hline No. & 1 & 2 & 4 & 5 & 6 \\
\hline 2 & $\begin{array}{l}2.62, \mathrm{~m} ; \\
2.79, \mathrm{~m}\end{array}$ & $\begin{array}{l}2.59, \text { ddd } \\
(17.7,10.1 \text {, } \\
4.6) ; \\
2.77, \text { ddd } \\
(17.7,6.4,4.6)\end{array}$ & & $\begin{array}{l}2.77, \mathrm{~m} ; \\
2.60, \mathrm{~m}\end{array}$ & $\begin{array}{l}2.77, \mathrm{~m} ; \\
2.60, \mathrm{~m}\end{array}$ \\
\hline 3 & $\begin{array}{l}2.01, \mathrm{~m} ; \\
2.26, \mathrm{~m}\end{array}$ & $\begin{array}{l}2.01, \mathrm{~m} ; \\
2.24, \mathrm{~m}\end{array}$ & & $\begin{array}{l}2.25, \mathrm{~m} ; \\
2.00, \mathrm{~m}\end{array}$ & $\begin{array}{l}2.25, \mathrm{~m} ; \\
2.00, \mathrm{~m}\end{array}$ \\
\hline 4 & $4.77, \mathrm{dd}(8.9,3.9)$ & $\begin{array}{l}4.76, \mathrm{dd} \\
(8.7,3.9)\end{array}$ & $6.50, \mathrm{~d}(1.0)$ & $\begin{array}{l}4.73, \text { ddd } \\
(13.2,8.9,3.9)\end{array}$ & 4.72, ddd $(12.1,9.1,3.8)$ \\
\hline $\begin{array}{l}5 \\
7\end{array}$ & $6.79, \mathrm{~s}$ & $6.75, \mathrm{~s}$ & $6.50, \mathrm{~s}$ & $6.66, \mathrm{~s}$ & $6.61, \mathrm{~s}$ \\
\hline 9 & $3.92, \mathrm{~s}$ & $3.90, \mathrm{~s}$ & $2.20, \mathrm{~d}(1.0)$ & $3.83, \mathrm{~s}$ & $3.79, \mathrm{~s}$ \\
\hline 10 & $5.31, \mathrm{q}(6.8)$ & $2.86, \mathrm{~m}$ & $3.83, \mathrm{~s}$ & $5.17, \mathrm{q}(6.8)$ & $5.17, \mathrm{q}(6.8)$ \\
\hline 11 & $1.48, \mathrm{~d}(6.8)$ & $3.56, \mathrm{t}(7.5)$ & $3.72, \mathrm{~s}$ & $1.45, \mathrm{~d}(6.8)$ & $1.44, \mathrm{~d}(6.8)$ \\
\hline $2^{\prime}$ & & & & $\begin{array}{l}2.77, \mathrm{~m} ; \\
2.60, \mathrm{~m}\end{array}$ & $\begin{array}{l}2.77, \mathrm{~m} ; \\
2.60, \mathrm{~m}\end{array}$ \\
\hline $3^{\prime}$ & & & & $\begin{array}{l}2.25, \mathrm{~m} ; \\
2.00, \mathrm{~m}\end{array}$ & $\begin{array}{l}2.25, \mathrm{~m} ; \\
2.00, \mathrm{~m}\end{array}$ \\
\hline $4^{\prime}$ & & & & $\begin{array}{l}4.73, \text { ddd } \\
(13.2,8.9,3.9)\end{array}$ & $\begin{array}{l}4.72, \mathrm{ddd} \\
(12.1,9.1,3.8)\end{array}$ \\
\hline $5^{\prime}$ & & & & $6.63, \mathrm{~s}$ & $6.58, \mathrm{~s}$ \\
\hline $9^{\prime}$ & & & & $3.79, \mathrm{~s}$ & $3.76, \mathrm{~s}$ \\
\hline $10^{\prime}$ & & & & $4.46, \mathrm{~m}$ & $4.48, \mathrm{~m}$ \\
\hline
\end{tabular}

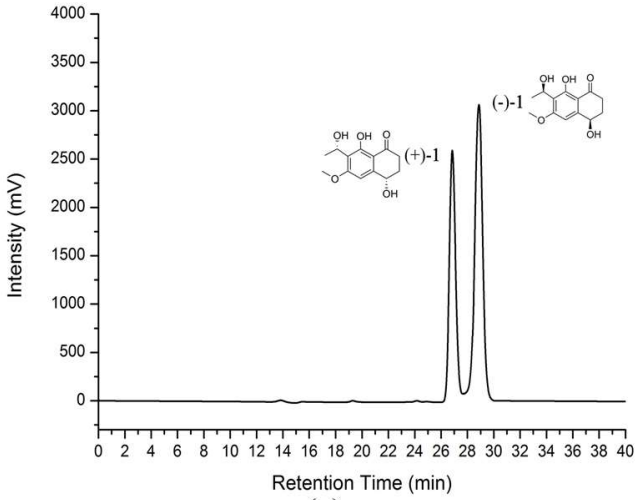

(a)



(b)

Figure 2. Chiral HPLC chromatogram (a); experimental and calculation ECD spectra (b) of ( \pm )-1.

Compound $( \pm)-\mathbf{2}$ was obtained as a light yellow powder. Its molecular formula was determined as $\mathrm{C}_{13} \mathrm{H}_{16} \mathrm{O}_{5}$ according to the positive HR-ESIMS ([M $\left.+\mathrm{Na}\right]^{+} m / z 275.0885$, calculated for $\left.\mathrm{C}_{13} \mathrm{H}_{16} \mathrm{O}_{5} \mathrm{Na}\right)$ and was the same as $( \pm)$-leptothalenone A. Through analysis of the NMR data of $( \pm)$-2 (Tables 1 and 2, Figure 3), the planar structure of $( \pm)-2$ was identified as the known compound 4,8-dihydroxy-7-(2-hydroxy-ethyl)-6-methoxy-3,4-dihydro-2H-naphthalen-1-one with positive optical rotation $\left([\alpha]_{D}^{20}=+28.0, c 0.1, \mathrm{MeOH}\right)[9]$, whose configuration has never been determined. Using the 
similar chiral HPLC purification method, $( \pm)-2$ was separated into two enantiomers, $(-)-\mathbf{2}$ and $(+)-\mathbf{2}$, which displayed opposite optical rotations $\left[(-)-2\left([\alpha]_{D}^{20}=-14.0, c 0.10, \mathrm{MeOH}\right)\right.$ and $(+)-2\left([\alpha]_{D}^{20}=15.1\right.$, c $0.07, \mathrm{MeOH})]$ and opposite Cotton effects in their CD spectra. The calculated ECD spectra of (4R)-2 and (4S)-2 agreed well with the experimental ECD spectra of (-)-2 and (+)-2 (Figure 4). Thus, the configuration of known compound (+)-2 was assigned as $4 R$, while the enantiomer (-)-2 was a new compound with the configuration of $4 S$.

Table 2. ${ }^{13} \mathrm{C}$ (100 MHz) NMR data of compounds 1, 2, and 4-6 (in $\mathrm{CD}_{3} \mathrm{OD}$ ).

\begin{tabular}{|c|c|c|c|c|c|}
\hline No. & 1 & 2 & 4 & 5 & 6 \\
\hline 1 & 204.6, C & 203.0, C & 162.1, C & $204.4, C$ & $204.4, C$ \\
\hline 2 & $36.1, \mathrm{CH}_{2}$ & $34.5, \mathrm{CH}_{2}$ & & $36.1, \mathrm{CH}_{2}$ & $36.1, \mathrm{CH}_{2}$ \\
\hline 3 & $32.7, \mathrm{CH}_{2}$ & $31.4, \mathrm{CH}_{2}$ & $156.3, \mathrm{C}$ & $32.7, \mathrm{CH}_{2}$ & $32.8, \mathrm{CH}_{2}$ \\
\hline 4 & $68.6, \mathrm{CH}$ & $67.2, \mathrm{CH}$ & $98.9, \mathrm{CH}$ & $68.6, \mathrm{CH}$ & 68.7, $\mathrm{CH}$ \\
\hline $4 a$ & $150.2, \mathrm{C}$ & $147.7, \mathrm{C}$ & $135.3, \mathrm{C}$ & $151.3, \mathrm{C}$ & $151.2, \mathrm{C}$ \\
\hline 5 & $102.2, \mathrm{CH}$ & $100.4, \mathrm{CH}$ & $135.8, \mathrm{C}$ & $101.9, \mathrm{CH}$ & $101.8, \mathrm{CH}$ \\
\hline 6 & $164.8, \mathrm{C}$ & 164.1, C & $158.5, \mathrm{C}$ & $166.2, \mathrm{C}$ & $166.1, \mathrm{C}$ \\
\hline 7 & $119.1, \mathrm{C}$ & $111.9, \mathrm{C}$ & $100.2, \mathrm{CH}$ & $116.7, \mathrm{C}$ & 116.7, C \\
\hline 8 & 162.7, C & 162.0, C & 161.0, C & $164.3, \mathrm{C}$ & $164.3, \mathrm{C}$ \\
\hline $8 a$ & $111.1, \mathrm{C}$ & 109.6, C & 101.2, C & $110.8, \mathrm{C}$ & $110.8, \mathrm{C}$ \\
\hline 9 & $56.4, \mathrm{CH}_{3}$ & $55.0, \mathrm{CH}_{3}$ & $19.5, \mathrm{CH}_{3}$ & $56.3, \mathrm{CH}_{3}$ & $56.2, \mathrm{CH}_{3}$ \\
\hline 10 & $63.4, \mathrm{CH}$ & $25.3, \mathrm{CH}_{2}$ & $56.4, \mathrm{CH}_{3}$ & $70.3, \mathrm{CH}$ & $70.4, \mathrm{CH}$ \\
\hline 11 & $22.2, \mathrm{CH}_{3}$ & $60.1, \mathrm{CH}_{2}$ & 61.6, $\mathrm{CH}_{3}$ & $20.0, \mathrm{CH}_{3}$ & $20.1, \mathrm{CH}_{3}$ \\
\hline $1^{\prime}$ & & & & 204.2, C & $204.2, \mathrm{C}$ \\
\hline $2^{\prime}$ & & & & $36.1, \mathrm{CH}_{2}$ & 36.1, $\mathrm{CH}_{2}$ \\
\hline $3^{\prime}$ & & & & $32.7, \mathrm{CH}_{2}$ & $32.8, \mathrm{CH}_{2}$ \\
\hline $4^{\prime}$ & & & & $68.6, \mathrm{CH}$ & $68.6, \mathrm{CH}$ \\
\hline $4 a^{\prime}$ & & & & $150.3, \mathrm{C}$ & $150.3, \mathrm{C}$ \\
\hline $5^{\prime}$ & & & & 101.3, CH & $101.3, \mathrm{CH}$ \\
\hline $6^{\prime}$ & & & & $165.9, \mathrm{C}$ & $165.9, \mathrm{C}$ \\
\hline $7^{\prime}$ & & & & 113.0, C & $113.1, \mathrm{C}$ \\
\hline $8^{\prime}$ & & & & 163.7, C & 163.6, C \\
\hline $8 a^{\prime}$ & & & & $110.7, \mathrm{C}$ & $110.7, \mathrm{C}$ \\
\hline $9^{\prime}$ & & & & $56.2, \mathrm{CH}_{3}$ & $56.1, \mathrm{CH}_{3}$ \\
\hline $10^{\prime}$ & & & & $59.6, \mathrm{CH}_{2}$ & $59.8, \mathrm{CH}_{2}$ \\
\hline
\end{tabular}

Compound 4 was obtained as a white crystal. The HR-ESIMS result $\left(m / z 237.0812[\mathrm{M}+\mathrm{H}]^{+}\right)$ suggested the molecular formula of 4 was $\mathrm{C}_{12} \mathrm{H}_{12} \mathrm{O}_{5}$ with seven degrees of unsaturation. The $1 \mathrm{D}$ and 2D NMR data indicated that compound 4 shared the same isocoumarin skeleton as 6,8-dihydroxy5-methoxy-3-methyl-1H-isochromen-1-one [10]. The only difference between them was that the hydroxyl group (8-OH) of the known compound was replaced by a methoxyl group $\left(8-\mathrm{OCH}_{3}\right)$ of 4 , which was further confirmed by the HMBC correlation of $\mathrm{H}-10$ to $\mathrm{C}-5$ and $\mathrm{C}-6$. Hence, compound 4 was assigned as 6-hydroxy-5,8-dimethoxy-3-methyl-1H-isochromen-1-one.

Compounds 5 and $\mathbf{6}$ were both isolated as a light brown amorphous powder from the same fraction using the RP-HPLC $\left[\mathrm{MeOH}-\mathrm{H}_{2} \mathrm{O} 60: 40, \mathrm{t}_{\mathrm{R}}(5)=52 \mathrm{~min}, \mathrm{t}_{\mathrm{R}}(6)=56 \mathrm{~min}\right]$, implying they were epimers. The different optical rotation $\left[[\alpha]_{D}^{20}=-11.9(\mathrm{MeOH}, c 0.21)\right.$ of $5,\left[[\alpha]_{D}^{20}=11.4(\mathrm{MeOH}, c 0.21)\right.$ of 6$]$ indicated that 6 was a stereoisomer of 5 . They had the same molecular formula $\mathrm{C}_{25} \mathrm{H}_{28} \mathrm{O}_{9}$, which was determined by HR-ESIMS at $m / z 495.1628$ (calculated for $\mathrm{C}_{25} \mathrm{H}_{28} \mathrm{O}_{9} \mathrm{Na}, 495.1626$ ), corresponding to 12 degrees of unsaturation. The IR spectrum displayed absorption at $3383 \mathrm{~cm}^{-1}$ indicative of the existence of hydroxyl group. The ${ }^{1} \mathrm{H}$ and ${ }^{13} \mathrm{C}$ NMR spectra of compounds 5 and 6 revealed the presence of 24 protons and 25 carbons (two ketone carbonyls, ten aromatic quaternary carbons, two aromatic methines, three methyls, five methylenes, three methine). There were $14 \mathrm{sp}^{2}$ carbon signals (two of which were carbonyls) that appeared pairwise in ${ }^{13} \mathrm{C}$ NMR spectrum indicating that 5 and $\mathbf{6}$ were heterodimers of naphthalenones. Detailed analysis of the ${ }^{1} \mathrm{H}_{-}{ }^{1} \mathrm{H} \mathrm{COSY}$ and $\mathrm{HMBC}$ spectra (Figure 3), compounds 5 and 6 had the same planar structures as two monomeric units leptothalenone A (1) and 10-norparvulenone 
(3). The two monomeric units were connected through an ether bond (10-O-10') based on the HMBC correlations from $\mathrm{H}-10^{\prime}$ to $\mathrm{C}-7^{\prime}$ and C-10. Therefore, the planar structures of 5 and $\mathbf{6}$ were defined as 1,5-dihydroxy-3-methoxy-8-oxo-5,6,7,8-tetrahydronaphthalen-2-yl)ethoxy)methyl)-4,8-dihydroxy-6methoxy-3,4-dihydronaphthalen-1(2H)-one.

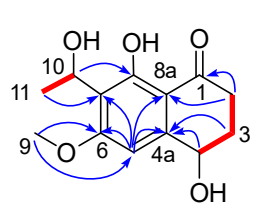

1



2
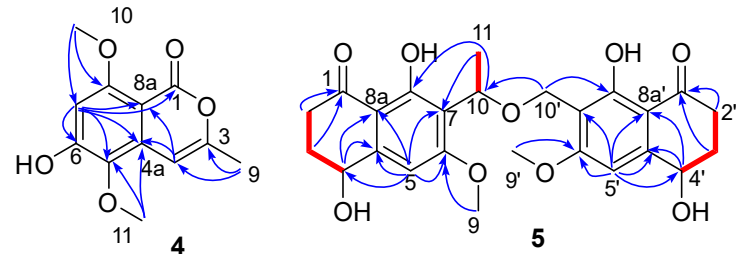

Figure 3. Key ${ }^{1} \mathrm{H}-{ }^{1} \mathrm{H}$ COSY (red line) and $\mathrm{HMBC}$ (blue arrow) correlations of compounds 1, 2, 4 and 5.
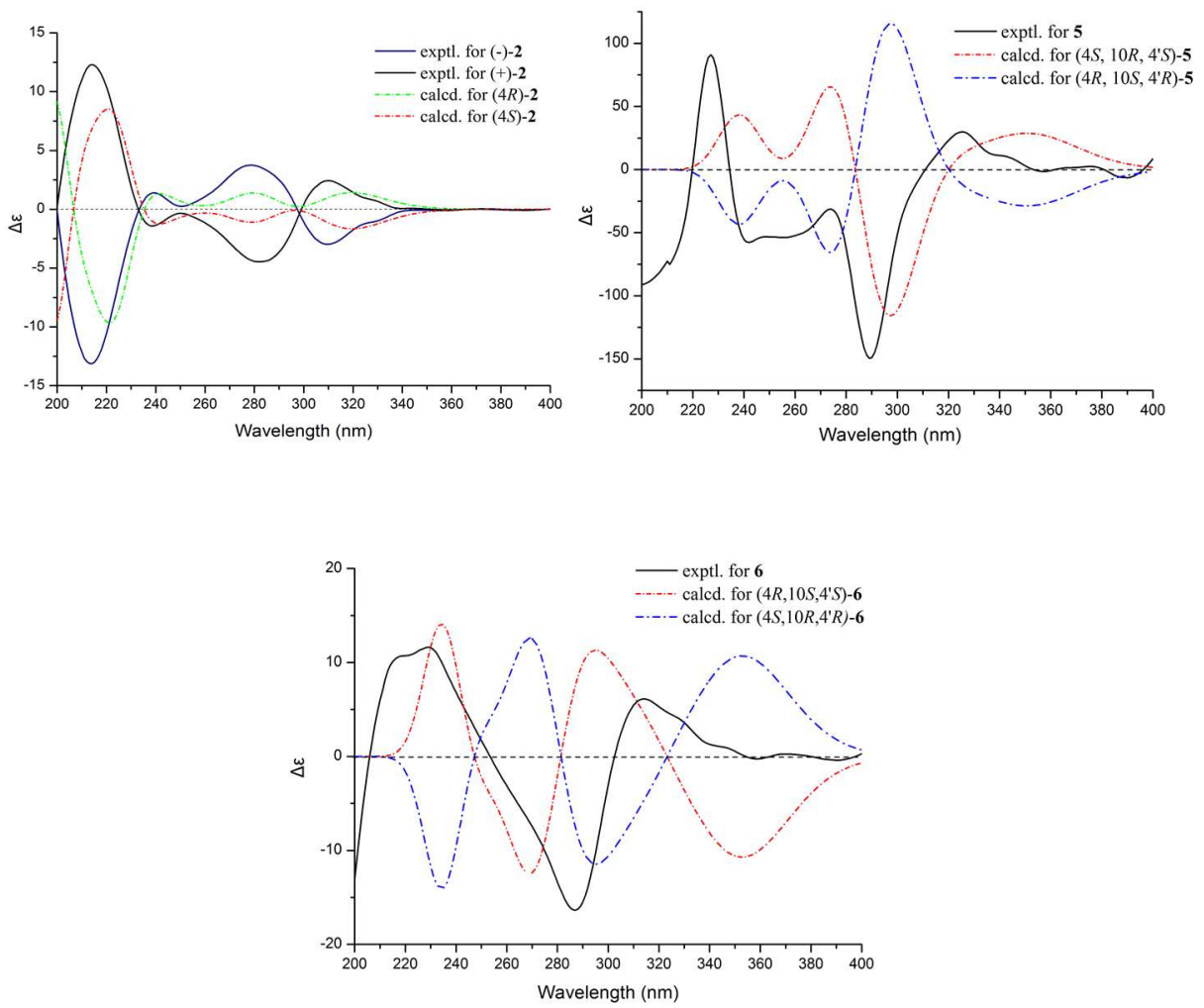

Figure 4. Experimental and calculation ECD spectra of 2, 5 and $\mathbf{6 .}$

The absolute configurations of $\mathbf{5}$ and $\mathbf{6}$ were established by comparing the experimental ECD data with the calculated values, in combination with biosynthetic considerations. Among the isolated monomeric naphthalenones, (+)-10-norparvulenone (3) was only obtained as an enantiomerically pure compound with $S$ configuration, supporting by the X-ray single-crystal diffraction (Figure S45). The biosynthetic pathway suggests that the configurations at C-4' of 5 and $\mathbf{6}$ were the same as those of the monomeric 10-norparvulenone (3). The ECD of the remaining four configurations $[(4 R, 10 S$, $\left.\left.4^{\prime} S\right)\left(4 S, 10 R, 4^{\prime} S\right)\left(4 R, 10 R, 4^{\prime} S\right)\left(4 S, 10 S, 4^{\prime} S\right)\right]$ was calculated by a quantum chemical method at the [B3LYP $/ 6-311+\mathrm{g}(2 \mathrm{~d}, \mathrm{p})]$ level. The theoretical ECD curve of $\left(4 S, 10 R, 4^{\prime} S\right)$ agreed well with the experimental ECD curve of $(-)-5$, and $\left(4 R, 10 S, 4^{\prime} S\right)$ was also in agreement with the experimental ECD curve of (+)-6 (Figure 4).

The known compound, (+)-10-norparvulenone (3) was identified by NMR, MS and optical rotation data analysis and comparison of spectroscopic data with the literature [9]. The optical rotation of 10-norparvulenone was $\left[[\alpha]_{D}^{20}=-27.0(\mathrm{MeOH}, c 0.21)\right.$, and that of 3 was $\left[[\alpha]_{D}^{20}=+16.6(\mathrm{MeOH}, c 0.21)\right.$, 
which indicated their absolute configurations were opposite. The absolute configuration of 3 was $4 S$ supported by $\mathrm{X}$-ray single-crystal diffraction using anomalous scattering of $\mathrm{Cu} \mathrm{K} \alpha$ radiation with Flack parameter $=0.00(6)$ (Figure S45). Thus, compound 3 was named as (+)-10-norparvulenone.

All the compounds were tested for their inhibition activity against LPS-activated NO production in RAW264.7 cells using the Griess assay. Compound $\mathbf{6}$ displayed moderate inhibitory effects on the production of $\mathrm{NO}$ with an $\mathrm{IC}_{50}$ value of $44.5 \pm 1.1 \mu \mathrm{M}$, compared to the positive control indomethacin $\left(\mathrm{IC}_{50}=37.5 \pm 1.6 \mu \mathrm{M}\right)$, while the other compounds showed no significant anti-inflammatory activity $\left(\mathrm{IC}_{50}>100 \mu \mathrm{M}\right)$. In addition, some of naphthalenones have been found to have cytotoxic activity according to previous studies $[2,5,11,12]$. Thus, all the isolated compounds were evaluated for their cytotoxicity against A549 (lung cancer), HeLa (cervical cancer), and MCF-7 (breast cancer) human cancer cell lines using MTT assay and displayed no cytotoxicity against all three cell lines at $50 \mu \mathrm{M}$.

\section{Materials and Methods}

\subsection{General Experimental Procedures}

Optical rotations were measured on an MCP 200 polarimeter by using an Na lamp (Shimadzu). UV spectra were obtained on a Blue Star A spectrophotometer. A Fourier transformation infra-red spectrometer coupled with infra-red microscope EQUINOX 55 (Bruker, Rheinstetten, Germany) was used to record the IR spectra. NMR spectra were obtained on a Bruker Avance $400 \mathrm{MHz}$ spectrometer with tetramethylsilane as the internal standard. HR-ESIMS data were obtained on a LTQ-Orbitrap LC-MS spectrometer (Thermo Corporation, Waltham, MA, USA). ESIMS spectra were obtained on an ACQUITY QDA (Waters Corporation, Milford, MA, USA). HPLC was carried out on an Essentia LC-16 with an SPD-16 Detector (Shimadzu, Shanghai, China). Column chromatography was carried out on silica gel (100-200 mesh, 200-300 mesh, Qing dao Marine Chemical Factory, Qingdao, China) and Sephadex LH-20 (GE Healthcare, Littile Chalfont, UK).

\subsection{Fungal Material}

The fungal strain 3608 was isolated from a crinoid collected in Xuwen, Zhanjiang City, Guangdong Province, China, in August 2014. It was identified as L. chartarum by ITS sequence, and the sequence data have been submitted to and deposited in the GenBank database under accession number MF980969. The fungal strain has been preserved at the school of marine science, Sun Yat-Sen University.

\subsection{Extraction, Isolation, and Characterization}

The fungus L. chartarum 3608 was cultured at room temperature $\left(25-30{ }^{\circ} \mathrm{C}\right)$ for one month in $1000 \mathrm{~mL}$ Erlenmeyer flasks containing rice medium, composed of $60 \mathrm{~mL}$ rice, $80 \mathrm{~mL} \mathrm{H}_{2} \mathrm{O}$, and $3 \%$ sea salt. After 30 days of cultivation, the fermented rice substrate of 170 flasks was extracted three times with $\mathrm{MeOH}$ to yield the organic extract $(70 \mathrm{~g})$. The organic extract was portioned into three phases by successive extraction with n-hexane $(43 \mathrm{~g}), \mathrm{CHCl}_{3}(8 \mathrm{~g})$, EtOAc $(17 \mathrm{~g})$.

The $\mathrm{CHCl}_{3}$ phase was subjected to a silica gel column $(6 \times 12 \mathrm{~cm}, 100-200$ mesh $)$ and was eluted with PE-EtOAc $(v / v, 80: 20,70: 30,60: 40,50: 50,40: 60,20: 80$ and 0:100, $400 \times 5 \mathrm{~mL}$ each gradient) to yield seven fractions (A-F). Fr. D was separated by silica gel CC ( $3.5 \times 12 \mathrm{~cm}, 200-300 \mathrm{mesh})$, eluted with PE-EtOAc $(v / v$ 70:30, 60:40, 65:45, 50:50, 55:45 and 30:70) and combined with the same fractions based on the TLC results to yield Fr.D.1-Fr.D.5. Fr.D.1 was further subjected to silica gel CC $(2 \times 12 \mathrm{~cm}, 200-300$ mesh) by isocratic elution by PE-EtOAc (65:35) to yield compound $4(6 \mathrm{mg})$. After recrystallization, the racemates of $\mathbf{1}$ and $\mathbf{2}$ were obtained from Fr.D.2 and Fr.D.3, respectively. The racemate of 1 was separated by chiral PR-HPLC $\left(30 \% \mathrm{CH}_{3} \mathrm{CN}-\mathrm{H}_{2} \mathrm{O}\right.$, flow rate $1 \mathrm{~mL} / \mathrm{min}$, Ultimate Amy-SR column $10 \times 250 \mathrm{~mm}, 5 \mu \mathrm{m})$ to yield $(-)-\mathbf{1}(5 \mathrm{mg}),(+)-\mathbf{1}(5 \mathrm{mg})$. The racemate of $\mathbf{2}$ was also separated by chiral PR-HPLC $\left(30 \% \mathrm{CH}_{3} \mathrm{CN}-\mathrm{H}_{2} \mathrm{O}\right.$, flow rate $1 \mathrm{~mL} / \mathrm{min}$, Ultimate Amy-SR column $10 \times 250 \mathrm{~mm}, 5 \mu \mathrm{m})$ to yield $(-)-2(7 \mathrm{mg})$, and $(+)-2(7 \mathrm{mg})$. Fr.E was subjected to silica gel CC $(3.5 \times 12 \mathrm{~cm}, 200-300 \mathrm{mesh})$ and eluted with PE-EtOAc (40:60) to yield 3 (300 mg). Fr.F was subjected to 
RP-C18 $(3.5 \times 12 \mathrm{~cm})$, eluted with $60 \% \mathrm{MeOH}-\mathrm{H}_{2} \mathrm{O}$, and then purified by PR-HPLC $\left(60 \% \mathrm{MeOH}-\mathrm{H}_{2} \mathrm{O}\right.$, flow rate $1 \mathrm{~mL} / \mathrm{min}$, Ultimate XB-C18 column $10 \times 250 \mathrm{~mm}, 5 \mu \mathrm{m})$ to yield $5(3 \mathrm{mg})$ and $6(2 \mathrm{mg})$, whose retention times were $52 \mathrm{~min}$ and $56 \mathrm{~min}$, respectively.

\subsection{1. (-)-Leptothalenone A ((-)-1)}

Light brown powder; $\left[[\alpha]_{D}^{20}=-24.8\left(\mathrm{MeOH}, c\right.\right.$ 0.47); UV (MeOH) $\lambda_{\max }(\log \varepsilon) 222(4.00), 286$ (3.92) nm; CD (MeOH) $\lambda_{\max }(\Delta \varepsilon) 214$ (-26.9), 238 (+2.74), 282 (+11.6), 310 (-6.24) nm; IR (neat) $v_{\max } 3381,2923,1626,1416,1286,1219,1157,1080,843 \mathrm{~cm}^{-1} ;{ }^{1} \mathrm{H}$ NMR $(400 \mathrm{MHz}, \mathrm{MeOD})$ and ${ }^{13} \mathrm{C}$ NMR (100 MHz, MeOD) data, see Tables 1 and 2; HR-ESIMS $m / z 275.0885$ [M + Na] ${ }^{+}$(calculated for $\left.\mathrm{C}_{13} \mathrm{H}_{16} \mathrm{O}_{5} \mathrm{Na}, 275.0890\right)$.

\subsection{2. (+)-Leptothalenone A ((+)-1)}

Light brown powder; $\left[[\alpha]_{D}^{20}=27.9(\mathrm{MeOH}, c 0.30) ; \mathrm{UV}(\mathrm{MeOH}) \lambda_{\max }(\log \varepsilon) 222\right.$ (3.91), 286 (3.79) $\mathrm{nm} ; \mathrm{CD}(\mathrm{MeOH}) \lambda_{\max }(\Delta \varepsilon) 214(+21.8), 238(-1.75), 282(-5.20), 310(+4.54) \mathrm{nm}$; IR (neat) $v_{\max }$ 3381, 2923, 1626, 1416, 1286, 1219, 1157, 1080, $843 \mathrm{~cm}^{-1} ;{ }^{1} \mathrm{H}$ NMR (400 MHz, MeOD) and ${ }^{13} \mathrm{C}$ NMR (100 MHz, MeOD) data, see Tables 1 and 2; HR-ESIMS $m / z 275.0885\left[\mathrm{M}+\mathrm{Na}^{+}\right.$(calculated for $^{2}$ $\left.\mathrm{C}_{13} \mathrm{H}_{16} \mathrm{O}_{5} \mathrm{Na}, 275.0890\right)$.

3.3.3. (-)-4,8-Dihydroxy-7-(2-hydroxy-ethyl)-6-methoxy-3,4-dihydro-2H-naphthalen-1-one ((-)-2)

White powder; $\left[[\alpha]_{D}^{20}=-14.0\left(\mathrm{MeOH}, c\right.\right.$ 0.10); UV (MeOH) $\lambda_{\max }(\log \varepsilon) 224$ (4.26), 287 (3.17) nm; $\mathrm{CD}(\mathrm{MeOH}) \lambda_{\max }(\Delta \varepsilon) 213$ (-13.1), 239 (1.40), 279 (3.75) nm; IR (neat) $v_{\max }$ 3374, 2945, 1622, 1417, 1292, 1211, 1138, 1092, $831 \mathrm{~cm}^{-1} ;{ }^{1} \mathrm{H}$ NMR (400 MHz, MeOD) and ${ }^{13} \mathrm{C}$ NMR (100 MHz, MeOD), see Tables 1 and 2; HR-ESIMS m/z $275.0885[\mathrm{M}+\mathrm{Na}]^{+}$(calculated for $\mathrm{C}_{13} \mathrm{H}_{16} \mathrm{O}_{5} \mathrm{Na}, 275.0890$ ).

\subsection{4. (+)-4,8-Dihydroxy-7-(2-hydroxy-ethyl)-6-methoxy-3,4-dihydro-2H-naphthalen-1-one ((+)-2)}

White powder; $\left[[\alpha]_{D}^{20}=15.1(\mathrm{MeOH}, c 0.07) ; \mathrm{UV}(\mathrm{MeOH}) \lambda_{\max }(\log \varepsilon) 224\right.$ (4.26), 287 (3.17) nm; $\mathrm{CD}(\mathrm{MeOH}) \lambda_{\max }(\Delta \varepsilon) 214$ (+12.3), 230 (-1.42), 282 (-4.47); IR (neat) $v_{\max } 3374,2945,1622,1417,1292$, 1211, 1138, 1092, $831 \mathrm{~cm}^{-1} ;{ }^{1} \mathrm{H}$ NMR (400 MHz, MeOD) $\delta 2.59$ (ddd, $\left.J=17.7,10.1,4.6 \mathrm{~Hz}, \mathrm{H}-2 \mathrm{a}\right) ; 2.77$ (ddd, $J=17.7,6.4,4.6 \mathrm{~Hz}, \mathrm{H}-2 \mathrm{~b}) ; 2.01$ (m, H-3a); 2.24 (m, H-3b); 4.76 (dd, J = 8.7, 3.9 Hz, H-4); 6.75 (s, H-5); 2.86 (m, H-10); 3.56 (t, $J=7.5 \mathrm{~Hz}, \mathrm{H}-11) ; 3.90$ (s, H-9); ${ }^{13} \mathrm{C}$ NMR (100 MHz, MeOD) $\delta 203.0$ (C, C-1); $34.5\left(\mathrm{CH}_{2}, \mathrm{C}-2\right) ; 31.4\left(\mathrm{CH}_{2}, \mathrm{C}-3\right) ; 67.2(\mathrm{CH}, \mathrm{C}-4) ; 147.7\left(\mathrm{CH}_{2}, \mathrm{C}-4 \mathrm{a}\right) ; 100.4(\mathrm{CH}, \mathrm{C}-5) ; 164.1(\mathrm{C}$, C-6); 111.9 (C, C-7); 162.0 (C, C-8); 109.6 (C, C-8a); $25.3\left(\mathrm{CH}_{2}, \mathrm{C}-10\right) ; 60.1\left(\mathrm{CH}_{2}, \mathrm{C}-11\right) ; 55.0\left(\mathrm{CH}_{3}, \mathrm{C}-9\right)$; HR-ESIMS $m / z 275.0885[\mathrm{M}+\mathrm{Na}]^{+}$(calculated for $\mathrm{C}_{13} \mathrm{H}_{16} \mathrm{O}_{5} \mathrm{Na}$, 275.0890).

\subsection{5. (+)-10-Norparvulenone (3)}

Yellow powder; $\left[[\alpha]_{D}^{20}=16.6\left(\mathrm{MeOH} c\right.\right.$ 0.14); UV (MeOH) $\lambda_{\max }(\log \varepsilon) 224(4.32), 285$ (4.18); 320 (3.72) nm; $\mathrm{CD}(\mathrm{MeOH}) \lambda_{\max }(\Delta \varepsilon) 216(+18.4), 240(-3.14), 274(-6.20), 305$ (4.75) nm; IR (neat) $v_{\max }$ $3379,2939,1616,1416,1290,1132,993,829 \mathrm{~cm}^{-1} ;{ }^{1} \mathrm{H}$ NMR $(400 \mathrm{MHz}, \mathrm{MeOD}) \delta 2.61$ (ddd, $J=12.9$, 8.2, 4.6 Hz, H-2a); 2.76 (ddd, J = 15.6, 8.5, 4.6 Hz, H-2b); 2.01 (m, H-3a); 2.25 (m, H-3b); 4.77 (dd, $J=9.0,3.8 \mathrm{~Hz}, \mathrm{H}-4) ; 6.77$ (s, H-5); $4.63(\mathrm{~s}, \mathrm{H}-9) ; 3.92\left(\mathrm{~s}, 6-\mathrm{OCH}_{3}\right) ;{ }^{13} \mathrm{C} \mathrm{NMR}(100 \mathrm{MHz}, \mathrm{MeOD}) \delta 204.6$ (C, C-1); $36.3\left(\mathrm{CH}_{2}, \mathrm{C}-2\right) ; 33.0\left(\mathrm{CH}_{2}, \mathrm{C}-3\right) ; 68.9(\mathrm{CH}, \mathrm{C}-4) ; 151.4(\mathrm{CH}, \mathrm{C}-4 \mathrm{a}) ; 102.1(\mathrm{CH}, \mathrm{C}-5) ; 166.1(\mathrm{C}$, C-6); 116.0 (C, C-7); 164.0 (C, C-8); 111.4 (C, C-8a); $53.1\left(\mathrm{CH}_{2}, \mathrm{C}-9\right) ; 56.7\left(\mathrm{CH}_{3}, 6-\mathrm{OCH}_{3}\right)$, ESIMS m/z $236.9[\mathrm{M}-\mathrm{H}]^{-}$.

\subsubsection{6-Hydroxy-5,8-dimethoxy-3-methyl-1H-isochromen-1-one (4)}

White powder; UV (MeOH) $\lambda_{\max }(\log \varepsilon) 244$ (2.76), 335 (2.07) nm; IR (neat) $v_{\max } 3192,2943,2858$, 1689, 1593, 1446, 1367, 1277, 1221, 1047, 980, 829, $746 \mathrm{~cm}^{-1} ;{ }^{1} \mathrm{H}$ NMR (400 MHz, MeOD) and ${ }^{13} \mathrm{C}$ NMR (100 MHz, MeOD) data, see Tables 1 and 2; HR-ESIMS $m / z 237.0812[\mathrm{M}+\mathrm{H}]^{+}$(calculated for $\left.\mathrm{C}_{12} \mathrm{H}_{13} \mathrm{O}_{5}, 237.0758\right)$. 


\subsection{7. ( $\left.4 S, 10 R, 4^{\prime} S\right)$-Leptothalenone B (5)}

Light brown amorphous powder; $\left[[\alpha]_{D}^{20}=-11.9(\mathrm{MeOH}, c 0.21) ; \mathrm{UV}(\mathrm{MeOH}) \lambda_{\max }(\log \varepsilon) 222\right.$ (3.35), 286 (3.20), $326(2.74) \mathrm{nm} ; \mathrm{CD}(\mathrm{MeOH}) \lambda_{\max }(\Delta \varepsilon) 227$ (91.0), 289 (-149.5), 327 (29.1) nm; IR (neat) $v_{\max }$ $3383,2933,1614,1290,1061,831 \mathrm{~cm}^{-1} ;{ }^{1} \mathrm{H}$ NMR $(400 \mathrm{MHz}, \mathrm{MeOD})$ and ${ }^{13} \mathrm{C}$ NMR (100 MHz, MeOD) data, see Tables 1 and 2; HR-ESIMS $\mathrm{m} / z 495.1628[\mathrm{M}+\mathrm{Na}]^{+}$(calculated for $\mathrm{C}_{25} \mathrm{H}_{28} \mathrm{O}_{9} \mathrm{Na}$, 495.1626).

\subsection{8. $\left(4 R, 10 S, 4^{\prime} S\right)$-Leptothalenone B (6)}

Light brown amorphous powder; $\left[[\alpha]_{D}^{20}=11.4(\mathrm{MeOH}, c 0.21) ; \mathrm{UV}(\mathrm{MeOH}) \lambda_{\max }(\log \varepsilon) 222\right.$ (3.35), 286 (3.20), 326 (2.74) nm; CD (MeOH) $\lambda_{\max }(\Delta \varepsilon) 227$ (11.5), 286 (-16.3), 315 (6.10) nm; IR (neat) $v_{\max }$ 3383, 2933, 1614, 1290, 1061, $831 \mathrm{~cm}^{-1} ;{ }^{1} \mathrm{H}$ NMR (400 MHz, MeOD) and ${ }^{13} \mathrm{C}$ NMR (100 MHz, MeOD) data, see Tables 1 and 2; HR-ESIMS $m / z 495.1628[\mathrm{M}+\mathrm{Na}]^{+}$(calculated for $\mathrm{C}_{25} \mathrm{H}_{28} \mathrm{O} 9 \mathrm{Na}, 495.1626$ ).

\subsection{Cytotoxic Assay}

All compounds were evaluated for their cytotoxicity against three human cancer cell lines, human lung adenocarcinoma (A549), human cervical carcinoma (HeLa), and the human breast adenocarcinoma cell line (MCF-7). The three tumor cell lines were generously provided by the cell bank of the Chinese Academy of Sciences (Shanghai, People's Republic of China). The cytotoxic activities of the tested compounds were assayed according to the MTT method by using 96 well plates [13]. In brief, the cells were cultured in MEM medium, supplemented with $10 \%$ fetal bovine serum in a humidified atmosphere with $5 \% \mathrm{CO}_{2}$ at $37^{\circ} \mathrm{C}$. Then, $198 \mu \mathrm{L}$ adherent cells at the density of $4 \times 10^{4} \mathrm{cell} / \mathrm{mL}$ were seeded into each well of the 96-well cell culture plates and incubated in $5 \% \mathrm{CO}_{2}$ at $37^{\circ} \mathrm{C}$ for $12 \mathrm{~h}$ to form a monolayer on the flat bottoms. Then, $2 \mu \mathrm{L}$ test compounds dissolved in DMSO were added at concentrations of $50 \mu \mathrm{M}$. The plate was then incubated in $5 \% \mathrm{CO}_{2}$ at $37^{\circ} \mathrm{C}$. After $24 \mathrm{~h}$, the supernatant per well was removed and subsequently added to $90 \mu \mathrm{L}$ fresh medium and $10 \mu \mathrm{L}$ MTT was added into each well and incubated for $4 \mathrm{~h}$. The supernatant per well was carefully removed, and $110 \mu \mathrm{L}$ DMSO was added. The plate was then vortex shaken for $15 \mathrm{~min}$ to dissolve blue formazan crystals. The optical density (OD) of each well was measured on a microplate reader (Multiskan GO, Thermo Scientific) at a wavelength of $490 \mathrm{~nm}$. Inhibition rate $(\%)=\left(\mathrm{OD}_{\text {control }}-\mathrm{OD}_{\text {treated }}\right) / \mathrm{OD}_{\text {control }} \times 100 \%$.

\subsection{Anti-Inflammation Bioassays}

The anti-inflammation activity of the pure compounds was evaluated based on the reported procedures [14].

\section{Conclusions}

In summary, seven naphthalenones and one isocoumarine, including six new compounds, were isolated from the marine-derived fungus Leptosphaerulina chartarum 3608. The structures of the new compounds were established by analysis of HR-ESIMS and NMR spectroscopic data, and the absolute configurations were further determined by comparison of the experimental and calculated ECD spectra. Among all isolated compounds, only compound $\mathbf{6}$ showed moderate anti-inflammatory activity with $\mathrm{IC}_{50}=44.5 \pm 1.1 \mu \mathrm{M}$. All secondary metabolites 1-6 exhibited no cytotoxicity against A549, HeLa, and MCF-7 cancer cell lines at $50 \mu \mathrm{M}$.

Supplementary Materials: The following are available online at http:/ / www.mdpi.com/1660-3397/16/5/173/s1. HR-ESIMS, NMR, CD spectra of the new compounds as well as other supporting data.

Author Contributions: Panpan Zhang, Lan Liu and Senhua Chen conceived and designed the experiments; Panpan Zhang performed the experiments; Chunxiu Jia, Jiajia Lang, Jing Li and Guangyuan Luo participated in the experimental process. Panpan Zhang, Sujun Yan and Senhua Chen analyzed the data.

Funding: This research was funded by the National Natural Science Foundation of China (Grant Nos. 21272289, 41606167, 41706148, and 51709287), the National Science and Technology Major Project of the Ministry of Science and Technology of China (2018ZX09735010), and the Guangzhou science and technology project (Grant No. 201804010476). 
Acknowledgments: This work was financially supported by grants from the National Natural Science Foundation of China (Grant Nos. 21272289, 41606167, 41706148, and 51709287), the National Science and Technology Major Project of the Ministry of Science and Technology of China (2018ZX09735010), and the Guangzhou science and technology project (Grant No. 201804010476). The authors are grateful to the members of the analytical group of the Test Center for data testing and the School of Medicine, Sun Yat-sen University for measuring the spectroscopic data and performing the biological assays.

Conflicts of Interest: The authors declare no conflict of interest.

\section{References}

1. Blunt, J.W.; Carroll, A.R.; Copp, B.R.; Davis, R.A.; Keyzers, R.A.; Prinsep, M.R. Marine natural products. Nat. Prod. Rep. 2018, 8, 53-68. [CrossRef] [PubMed]

2. Barnes, E.C.; Jumpathong, J.; Lumyong, S.; Voigt, K.; Hertweck, C. Daldionin, an Unprecedented Binaphthyl Derivative, and Diverse Polyketide Congeners from a Fungal Orchid Endophyte. Chem. Eur. J. 2016, 1, 4551-4555. [CrossRef] [PubMed]

3. Prabpai, S.; Wiyakrutta, S.; Sriubolmas, N. Phytochemistry Letters Antimycobacterial dihydronaphthalenone from the endophytic fungus Nodulisporium sp of Antidesma ghaesembilla. Phytochem. Lett. 2015, 13, 375-378. [CrossRef]

4. Mentel, R.; Lindequist, U.; Jansen, R.; Drugs, M.; Sea, B. Balticols A-F, New Naphthalenone Derivatives with Antiviral Activity, from an Ascomycetous Fungus. Chem. Biodivers. 2009, 6, 127-137.

5. Li, Y.X.; Himaya, S.W.A.; Dewapriya, P.; Kim, H.J.; Kim, S.K. Anti-proliferative effects of isosclerone isolated from marine fungus Aspergillus fumigatus in MCF-7 human breast cancer cells. Process Biochem. 2015, 49, 2292-2298. [CrossRef]

6. Abdel-lateff, A.; Ko, G.M.; Fisch, K.M.; Ho, U.; Jones, P.G.; Wright, A.D. New Antioxidant Hydroquinone Derivatives from the Algicolous Marine Fungus Acremonium sp. J. Nat. Prod. 2002, 65, 1605-1611. [CrossRef] [PubMed]

7. Zhao, D.; Shao, C.; Wang, C.; Wang, M.; Yang, L.; Wang, C. Naphthalenones and Depsidones from a Sponge-Derived Strain of the Fungus. Molecules 2016, 21, 4-9.

8. Bös, M.; Canesso, R.; Inoue-Ohga, N.; Nakano, A.; Takehana, Y.; Sleight, A.J. O-Methylasparvenone, A Nitrogen-free Serotonin Antagonistt. Bioorg. Med. Chem. 1997, 5, 2165-2171. [CrossRef]

9. Hao, G.; Zhang, Q.H.; Jiang, M.M.; Tang, J.S.; Miao, C.D.; Kui, H.; Michio, N.; Wang, N.L.; Yao, X.S. Polyketides from a marine sponge-derived fungus Mycelia sterilia and proton-proton long-range coupling. Magn. Reson. Chem. 2008, 46, 1148-1152. [CrossRef] [PubMed]

10. Chen, S.; Liu, Y.; Liu, Z.; Cai, R.; Lu, Y.; Huang, X.; She, Z. Isocoumarins and benzofurans from the mangrove endophytic fungus Talaromyces amestolkiae possess $\alpha$-glucosidase inhibitory and antibacterial activities. RSC Adv. 2016, 6, 26412-26420. [CrossRef]

11. Shah, R.; Stadler, M.; Anke, H.; Sterner, O. Naphthalenone and phthalide metabolites from Lachnum papyraceum. J. Nat. Prod. 1997, 60, 804-805.

12. Chen, G.; Pi, X.M.; Yu, C.Y. A new naphthalenone isolated from the green walnut husks of Juglans mandshurica Maxim. Nat. Prod. Res. 2015, 29, 174-179. [CrossRef] [PubMed]

13. Wang, J.; Xu, Q.; Zheng, M.; Ren, H.; Lei, T.; Wu, P.; Zhou, Z.; Wei, X.; Tan, J. Bioactive 30-Noroleanane Triterpenes from the Pericarps of Akebia trifoliata. Molecules 2014, 19, 4301-4312. [CrossRef] [PubMed]

14. Zhang, P.; Li, Y.; Jia, C.; Lang, J.; Niaz, S.-I.; Li, J.; Yuan, J.; Yu, J.; Chen, S.; Liu, L. Antiviral and anti-inflammatory meroterpenoids: Stachybonoids A-F from the crinoid-derived fungus Stachybotrys chartarum 952. RSC Adv. 2017, 7, 49910-49916. [CrossRef]

(c) 2018 by the authors. Licensee MDPI, Basel, Switzerland. This article is an open access article distributed under the terms and conditions of the Creative Commons Attribution (CC BY) license (http://creativecommons.org/licenses/by/4.0/). 